\title{
Bringing Our Boy Home: The Tomb of the Unknown Warrior and Contemporary War Remembrance
}

\section{GARETH PHIPPS}

In November 2004 the remains of an unidentified New Zealand serviceman were brought home from France and placed in the Tomb of the Unknown Warrior outside the National War Memorial in Wellington. A casualty of the First World War, the Unknown Warrior represented one of the almost 30,000 New Zealand war dead buried overseas - 9,000 of whom have no known grave. ${ }^{1}$ On Armistice Day 2004 his remains were interred in a specially constructed tomb built to provide a distinctly New Zealand memorial for the country's servicemen and women. According to its designer, Kingsley Baird, the tomb 'is an expression of the nation's memory and a cross-cultural language of remembrance [that] combines Maori and Pakeha ritual, symbolic, and visual elements ... to express remembrance specific to New Zealand's contemporary identity.'2

The return of the Unknown Warrior was a significant event for New Zealand. An estimated 100,000 people lined the streets of Wellington to watch his casket make its way from Parliament to its final resting place, and the ceremonial programme was broadcast live on national television.

In this article I discuss the return of New Zealand's Unknown Warrior in order to explore how aspects of memory, ritual and commemoration shape contemporary war remembrance. Drawing on comments left in visitor books and on-site interviews with visitors to the memorial, I analyse institutional objectives set out in the design and planning of the Tomb of the Unknown Warrior, and the political and popular motivations that led to its construction. I argue that visitors combine elements of individual memory, civil remembrance and national commemoration to construct meaning at the Tomb and form connections with the Unknown Warrior. Their responses are influenced by the impact of 'grassroots' interest in war remembrance and soldier ancestors, and an understanding of the experience of war and death, public ritual and state involvement in commemoration. This article looks beyond a government-driven ideology of nation-building to throw 
light on the interplay of memory, state ritual and war commemoration in the construction and public reception of a contemporary war memorial.

\section{War memory and commemoration}

Over the last three decades public interest in war memory and war commemoration has increased considerably. Worldwide, this trend has been characterized by the proliferation of high-profile anniversaries commemorating key events of the world wars, increased interest in capturing the memories of veterans before they disappear, and the greater visibility of the Holocaust and its survivors in public consciousness. ${ }^{3}$

Public interest in war memory has been accompanied by a proliferation of studies on the cultural legacy of war. Since the 1970s a range of interdisciplinary studies have explored war memorials, trench literature, battlefield pilgrimages and a host of other representations and signifying practices in the aftermath of military conflict. ${ }^{4}$ This wave of war memory scholarship has opened up new areas of inquiry into the remembrance of the Holocaust and the Vietnam War, while the study of war memory has become an established element in various national historiographies. ${ }^{5}$

In New Zealand, war memory and commemoration have been subjects of increasing interest. Historian Jock Phillips believes the 'rediscovery' of New Zealand's war memory began during the 1980s with oral history interviews of the last remaining veterans from Gallipoli and other First World War battles. ${ }^{6}$ Over the last decade, publications about the commemoration of war have continued to grow. Oral history projects have recorded the experiences of New Zealanders during the Second World War and Vietnam War, while fresh research on the impact of war photography, memorial-building and memorializing in general, have helped to broaden war remembrance discourse within New Zealand. ${ }^{7}$ One of the most popular areas of study within this wave of war memory scholarship has been the war memorial. ${ }^{8}$

\section{War memorials and the nation}

According to Benedict Anderson, war memorials help evoke the notion of sacrifice that may be required from citizens as a cost of belonging, and present the means by which the nation-state persuades its citizens to die for it. ${ }^{9}$ The First World War was a watershed moment when commemoration of the dead circulated political ideas about the war and war memorials played a particularly important role in promoting the nation. ${ }^{10}$ Listing the names of war dead on surrogate graves reconfigured the meaning of death as collective sacrifice. ${ }^{11}$

A new democratic style of war memorial emerged, in which iconography moved from the commemoration of generals or rulers to the acknowledgement 
of ordinary soldiers. This was epitomized by the burying of an unknown soldier in Westminster Abbey in London, and under the Arc de Triomphe in Paris, following the First World War. ${ }^{12}$ What George Mosse calls the 'cult of the fallen soldier' developed from the practice of memorializing unknown soldiers to represent the sacrifice of the rank and file..$^{13}$ They became places of pilgrimage for the nation.

Writing at the beginning of the 1990s Mosse predicted that the cult of the fallen war dead would not survive the pressures of modern society. Challenges to nationalism, illustrated by the collapse of the Soviet Union and emergence of the European Union seemed destined to relegate the cult into history. Over the last two decades however, memorials to unknown soldiers continue to be created. In 1993, Australia repatriated the remains of a man who died in the First World War and interred them in a tomb at the Australian War Memorial, while similar projects were carried out by Canada in 2000 and New Zealand in 2004.

\section{The New Zealand Unknown Warrior}

Britain and France were the first to entomb an unknown soldier following the end of the war. Over the next decade these ceremonies were replicated in almost every country that fought in the war. By the 1930s there were tombs of unknown soldiers throughout Europe and in America. Despite this frenzy of ceremony and monument-making, the British empire had no tombs for unknown soldiers outside London. There had been plenty of proposals from the Dominions, especially Australia, Canada and New Zealand, but these were rejected on the basis that the body in Westminster Abbey represented the entire empire. ${ }^{14}$ This argument held sway for seventy years.

New Zealand's campaign to bring home the remains of an unknown serviceman began in November 1921 - a year after the British Unknown Soldier was interred in Westminster Abbey. On Armistice Day the Member of Parliament for Waitomo, William Jennings (who lost a son at Gallipoli) asked Prime Minister William Massey whether Cabinet would consider bringing home the remains 'of one of our unknown boys'. ${ }^{15}$ After some deliberation Cabinet decided not to proceed with the idea, presumably due to the financial costs involved and the existence of the Westminster tomb. ${ }^{16}$

The idea resurfaced after the Second World War, as part of an unsuccessful campaign by the New Zealand Returned Services Association (NZRSA) to secure completion of the National War Memorial. Up to this point, construction of the national memorial had been a piecemeal affair. Plans to build it in Wellington had initially begun in 1919 but took 13 years to complete. ${ }^{17}$ During this period there were numerous suggestions on what form the memorial should take but the government finally decided on a 
50-metre high carillon tower. ${ }^{18}$ This was to be the central feature of a complex of buildings, which would include a national art gallery and national museum. The site chosen was Mount Cook, a prominent hill that could be seen from many parts of the city. The Carillon was opened on Anzac Day ${ }^{19}$ 1932 in front of a crowd of 10,000, while the National Art Gallery and Dominion Museum - predecessor to the Museum of New Zealand Te Papa Tongarewa - were formally opened in August 1936..$^{20}$ Although architects had planned to include a Hall of Memories adjoining the Carillon to serve as a commemorative chapel, the Great Depression of the 1930s and the outbreak of the Second World War forced the postponement of this addition. In 1950 the NZRSA submitted a proposal to the government outlining their plans for the further development of the memorial, which included provision for the construction of tombs for two unknown warriors from each world war. ${ }^{21}$ The cost of the NZRSA proposal, an estimated $£ 250,000$, proved prohibitive however and development stalled until the Hall of Memories was completed in 1964.

Fifty years passed before the idea of a New Zealand Unknown Warrior was broached again. In 1999 military historian Ian McGibbon recommended that the Department of Internal Affairs investigate the possibility of repatriating the remains of a New Zealand unknown soldier as a high-profile millennium project. McGibbon cited the unveiling of Australia's Tomb of the Unknown Soldier in 1993 and suggested that a New Zealand soldier equivalent would be '. . . a visible and dramatic way of honouring and remembering the nation's war dead'. ${ }^{22}$ McGibbon brought up the idea again two years later at the launch of his guide to New Zealand battlefields on the Western Front. ${ }^{23}$ This time the idea gained traction, with Prime Minister Helen Clark, among the audience that night, reacting enthusiastically to the suggestion.

By early 2002, the Prime Minister had given approval and a project team was established under the leadership of the Ministry for Culture and Heritage. ${ }^{24}$ One of its first tasks was to develop a media strategy regarding key messages and themes. The Tomb was presented as a national focus of remembrance for those who sacrificed their lives in the service of New Zealand. It was described as a symbol of unity and national identity, which would link all generations of New Zealanders and provide a place for war veterans to pay tribute to their comrades. As for the Unknown Warrior, he was, first and foremost, a New Zealander coming home and his remains represented and honoured all New Zealanders who were lost to their families through war. The fact that his identity was unknown meant that he could symbolically represent all New Zealand war dead, regardless of ethnicity or religion. In terms of design, the Tomb was to be a distinctively New Zealand 
memorial, incorporating symbols, language and materials that reflected our national identity. ${ }^{25}$

In December 2002 the Ministry called for expressions of interest for the tomb design. The winning design was submitted by Robert Jahnke, an established sculptor with work commissioned throughout the country. ${ }^{26}$ Jahnke's design was a pyramid-shaped Tomb, which alluded both to the outstretched arms of a Maori ancestral meeting house (whare tupuna) and an upright canoe (waka) hull - used in Maori custom to signify the passing of a person of great authority and influence (mana). This design involved, however, remodelling the National War Memorial's forecourt and steps, and demolishing the original staircase, pool and walls. New disabled access would require the removal of 70 -year-old native pohutukawa trees.

The Jahnke tomb soon attracted the criticism of interest groups concerned at the size and invasiveness of the design. Among the most vocal were members of the Professional Historians' Association of New Zealand/ Aotearoa (PHANZA) who believed that the removal of the formal entrance of the National War Memorial constituted a major, irreversible alteration to a place of great national significance. ${ }^{27}$ National media outlets picked up on the article and the issue gained some publicity. ${ }^{28}$

More tangible signs of protest followed. On Anzac Day 2003, posters campaigning against the renovation of the forecourt were plastered on the steps and forecourt at the memorial prior to the televised Anzac Day service. ${ }^{29}$ Despite the negative media coverage the Ministry pushed ahead with the project. ${ }^{30} \mathrm{~A}$ variety of interested parties, including some PHANZA members, formed the Serious About Heritage Society (SAHS) which lodged an appeal in the High Court against the Wellington City Council's decision not to include the memorial's steps and forecourt in the heritage listing. The appeal was successful and the resource consent was overturned. The Ministry was forced to submit a new application and project completion was delayed till November 2004.

The court decision prompted an official change in attitude toward the National War Memorial. Consultation regarding the design was far more rigorous. A new conservation plan for the memorial was commissioned and options for the tomb were peer-reviewed by external organizations such as PHANZA, the New Zealand Institute of Architects, and SAHS before a new resource consent application was submitted. ${ }^{31}$

In May 2004, a new design by artist and sculptor Kingsley Baird was selected which conveyed the Ministry's design brief while respecting the existing site of the memorial.

Built into the forecourt steps of the National War Memorial, the classically shaped tomb featured distinctive New Zealand symbolism and iconography. 
Along the base of the tomb were etched the words of a ceremonial call (karanga), in English and Maori, calling the unknown warrior back home to New Zealand. Crosses of Takaka marble were set into the black granite of the tomb to represent the unknown warrior's comrades who died in service and remain overseas. The bronze lid features four inlaid greenstone (pounamu) crosses, alluding to the Southern Cross constellation, which forms part of the New Zealand flag. ${ }^{32}$

On 6 November 2004 the remains of an unidentified New Zealand soldier of the First World War were exhumed by Commonwealth War Graves Commission staff from the Caterpillar Valley Cemetery on the Somme in northern France. They were returned to the care of a New Zealand Defence Force contingent at a ceremony at the New Zealand Memorial at Longueval in France, and then flown back to Wellington by the Royal New Zealand Air Force. On 10 November 2004, the Unknown Warrior was welcomed at Parliament by the Governor-General and Prime Minister. He lay in state until a memorial service was held the following morning at the Wellington Cathedral of St Paul. During the service, Prime Minister Helen Clark paid tribute to:

A warrior who has lain for close to 90 years in foreign soil, and who has now been called back to serve his country once more . . . In being chosen to represent more than 30,000 others who died in the service of our country, the Unknown Warrior has enormous symbolism for New Zealand. All we know of him is that he died on the Western Front, and that he was one of us. We are the future generations for whom he lost his life. In a very real sense he is one of the foundations of today's society ... This is not just an occasion of sorrow, but also an opportunity to pay tribute to our New Zealand servicemen and women who lost their lives serving our nation. We acknowledge that they gave their lives in our country's service, and that all of us today, in some sense, owe them the lives we now lead. ${ }^{33}$

The memorial service was followed by a military funeral procession through central Wellington to the Memorial where the unknown warrior was laid to rest.

\section{War memorials and psychology}

The return of the unknown warrior was enthusiastically embraced by the New Zealand public - an estimated 10,000 people filed past his coffin as he lay in state at Parliament, while another 100,000 lined the streets of Wellington to watch the military procession to the National War Memorial. Advocates of psychological explanations for war memory and commemoration suggest this popular reception was driven by a human desire for psychological 
compensation in response to the traumatic death of friends and family in war. ${ }^{34}$ Memorials gave grieving families a public place to mourn, and provided a focus for the rituals, rhetoric, and ceremonies of bereavement.

The political and psychological paradigms have long dominated studies of war memorialization, but recent studies have begun to question the validity of their mutually exclusive approaches. It has been suggested that the emphasis on politics or on death or suffering obscures the complex relations involved in war memory, especially between individual memory, civil remembrance and the commemorative practices of the state. ${ }^{35}$ Both approaches tend to ignore individual subjectivity, under-conceptualizing the complex dynamics of personal memory and the extent to which it is constructed through commemorative practices at local and state level. ${ }^{36}$

\section{Contemporary war commemoration}

Over the last three decades war memorializing in the West has taken place in what Martin Shaw calls a 'post-military society'. ${ }^{37}$ The participatory massmilitarism that of the world wars has long disappeared and the narrative of nation building, which defined post-First World War memorializing, has been challenged by recent historical developments. The collapse of the Soviet Union and the creation of the European Union have challenged the hegemony of the territorial nation state. The nature of warfare has also changed. In the Western world, conflicts between sovereign nation-states are rare. ${ }^{38}$ Over the last decade, the beginning of the United States-led 'War on Terror' has seen states in conflict with small groups acting outside the boundaries of state politics. ${ }^{39}$

These changes have opened up the possibility for different stories to emerge out of memorials to past conflicts. ${ }^{40}$ As communities have begun to re-examine their war history, omissions and discoveries have been made, prompting new interpretations and new narratives. An example of this is the Blackball war memorial on the West Coast of New Zealand. Unveiled in March 2008 during centenary commemorations of the 1908 Blackball mine strike, the war memorial represented a significant re-evaluation of local history. ${ }^{41}$ Blackball was historically a socialist stronghold, and in the aftermath of both world wars strong anti-war feelings prevented a war memorial being built. But by the twenty-first century Blackball was a very different community. The mining industry and the trade union movement no longer dominated the area - and local residents endorsed the war memorial project. $^{42}$

Within this context of the reinterpretation of war commemoration, new types of memorials have emerged. The rise of 'counter memorials' to the Holocaust in Germany are prime examples of this commemorative shift. ${ }^{43}$ Memorials such as the Harburg Monument against Fascism and the Invisible 
Monument in Saarbrücken were the antithesis of traditional war memorial design, built into the ground and designed to disappear instead of standing for all time. ${ }^{44}$ One of the most famous counter memorials is the Vietnam Veterans Memorial in Washington DC. The memorial is comprised of two V-shaped intersecting black granite walls inscribed with the names of 58,175 American dead and missing from the Vietnam War. Designed as an opening or wound in the earth that symbolizes the loss of the soldiers, the memorial caused controversy because it avoided traditional heroic imagery and did not subsume individual deaths within a national narrative.

\section{Contested sites?}

As contemporary societies begin to re-examine and reinterpret how they remember war, what impact has this made on recent war memorial projects? The building of New Zealand's Tomb of the Unknown Warrior, completed in 2004, attracted its share of criticism. Alongside opposition to the design there were also rumblings of discontent regarding the name of the Tomb. While Australia and Canada repatriated an Unknown Soldier, New Zealand chose to commemorate an Unknown Warrior. Media reports suggested that the NZRSA had been unhappy with the choice, arguing the term sounded too aggressive and more commonly associated with a Maori warrior or rugby league player. ${ }^{45}$ Warrior was too grand a name and would not represent those who served behind the frontline. No formal objection was made during the planning process and in the end the NZRSA agreed with the recommendations of the New Zealand Defence Force (NZDF), who argued that the term 'warrior' better represented the three military services - army, navy, and air force - as well as New Zealand's Maori traditions.

Despite the disagreements, the public responded enthusiastically to the repatriation of the Unknown Warrior and visited the National War Memorial in large numbers. For some historians, the success of the project is further evidence that the 'contested' nature of contemporary war remembrance has been over-emphasized. Remarking on war commemoration in Australia at the end of the twentieth century, Ken Inglis argues that increased attendances at Anzac Day commemorations, government subsidies for memorial restoration projects, and the 'new' Unknown Soldier of 1993 mark a decline in the contested nature of war remembrance. ${ }^{46}$ Stephen Clarke identifies a similar lack of public contestation within the context of New Zealand war remembrance. While war and national security issues have receded from public view in the years following the Vietnam War and the thawing of the Cold War, New Zealand has experienced a steady increase in 'grassroots' support for war remembrance. This popular support has been accompanied by the increased presence of New Zealand history in the school curriculum and public history, as well as a growth of interest in genealogy and the 
search for soldier ancestors. The state has re-entered the remembrance arena on the back of this wave of public enthusiasm, and memorial projects such as the Tomb of the Unknown Warrior have been undertaken in the name of nation-building and national identity. ${ }^{47}$

While war commemoration has been one of the cornerstones of the development of national identity in Australia, Canada and New Zealand, the narrative of nationalism it promotes has been criticized for its inconsistencies and omissions. Liz Reed underlines the fact that war memorializing in Australia remains the exclusive preserve of male white Australians. The problematic nature of incorporating the Aboriginal story within the Anzac mythology, especially given the debate surrounding the issue of 'frontier' warfare between white settlers and Aborigines, has seen the indigenous story subsumed within the Australian 'digger' narrative. ${ }^{48}$ Some small efforts have been made to rectify this. In 1993 an Aboriginal Memorial was unveiled on a rock behind the AWM in Canberra. Inscribed with the words 'Remembering The Aboriginal People Who Served In The Australian Forces', the small plaque was placed there as part of the United Nation's International Year for the World's Indigenous People. ${ }^{49}$ A year later the Aboriginal community lay to rest its own 'Unknown Soldier'. Farrier Quartermaster Sergeant George Kennedy was Australia's highestranking Aboriginal soldier of the First World War, and the only Aboriginal ex-servicemen in New South Wales to be granted land as a soldier settler. Yet for years his grave lay unmarked except for a numbered peg. Dissatisfied with the lack of recognition, Kennedy's family, with assistance from the Office of War Graves, RSL and the Australian Institute of Aboriginal and Torres Strait Islander Studies, organized a headstone for his grave. The new headstone, inscribed with the statement 'In Commemoration Of All A boriginals That Served In The Services', was unveiled during a televised ceremony on Anzac Day 1994. ${ }^{50}$

In recent years Canada has made efforts to acknowledge the service and sacrifice of Aboriginal peoples in the armed forces. During the burial of the Unknown Soldier in 2000, First Nations symbols were incorporated into the ceremony. Along with soil from the different provinces and territories of Canada, a feather and tobacco and were placed in the tomb by a representative of the First Nations people..$^{51}$ Both items are important in First Nations ritual practices - a fallen eagle feather symbolizes a fallen warrior, while the ritualized use of tobacco provides a link with the spirit world. ${ }^{52}$ Just over a year later a National Aboriginal Veterans Monument was unveiled in Ottawa. Situated near the National War Memorial, it honours Aboriginal Canadians who served in Canada's armed forces from the First World War to the present. ${ }^{53}$ Four human figures, representing the Inuit, Métis, and other First Nations peoples, are depicted on the memorial. Two 
carry weapons, and two hold items of spiritual significance. Above them is an eagle, symbolizing the creator and spirit of the Aboriginal peoples. On each corner there are four animals - wolf, elk, bear and buffalo - of special significance in Aboriginal cultures.

In New Zealand, bicultural elements of remembrance have become integral parts of recent memorial projects. ${ }^{54}$ Maori symbolism was incorporated into the design of high-profile New Zealand memorials in Canberra in 2001 and London in 2006, while cultural elements were included in the ceremonial service for each project. Substantial bicultural ritual also accompanied the creation of the Tomb of the Unknown Warrior. Te Ati Awa elder (kaumatua) Sam Jackson blessed the site at the beginning and end of construction, while the Unknown Warrior was accompanied from France to New Zealand by the New Zealand Defence Force Maori Cultural Group - in accordance with Maori protocol that the dead should never be left alone. ${ }^{55}$

While this pluralism may seem democratic and inclusive, more questions are being asked about the way certain events have been inscribed in our national consciousness while other events remain relatively unmemorialized. Rachel Buchanan argues that New Zealand's war memorializing continues to ignore or marginalize parts of its war history - most notably the internal New Zealand Wars of the nineteenth century. ${ }^{56}$ Focusing on the recently completed tomb Buchanan writes:

[W] hat is clearly troubling about the memorial - to me at least - is the way this overtly bicultural tomb ignores New Zealand's wars of foundation. . . Memories of these complicated foundational wars, including war stories associated with the site on which the tomb has been built, nibble away at this elegant new memorial, diminishing its mana (status) and power. ${ }^{57}$

For Buchanan, the absence of any reference to the New Zealand Wars suggests that these wars have disappeared from the collective national memory. ${ }^{58}$ Comments such as these raise interesting questions regarding the interpretation of war memorials within New Zealand - just whose sacrifice is (or is not) being memorialized in projects such as the Tomb of the Unknown Warrior, and how is this interpreted by visitors to these sites?

\section{Visitor research}

Individuals' responses to war remembrance represent a fresh area of inquiry in the field of war memory and commemoration. Much of the literature has focused on the production and function of war memorials in the aftermath of the world wars of the twentieth century, but does not shed light on the individual responses of those who visited them at the time of their unveiling. The First World War generation of veterans and bereaved families have 
disappeared, while the numbers of Second World War eye-witnesses are thinning rapidly.

Visitor research provides a way to move beyond the superficial 'reading' of war memorials and enables investigation into the ways that individuals actively make meaning at these sites. Studies by Alistair Thomson and Bruce Scates have begun to explore the subjective element of contemporary war commemoration. ${ }^{59}$ Scates' investigation of personal pilgrimages to the First World War battlefields of Gallipoli and the Western Front is one of the first attempts to record visitors' own accounts of their experiences. In what he termed a 'participant history' Scates used visitor surveys and interviews to trace the experience of 700 Australian and New Zealand pilgrims at various sites of significance in Turkey and France. ${ }^{60}$ Through this visitor research he discovered that these modern day pilgrims were motivated and influenced, to varying degrees, by emotion, memory, family (history), and national history.

To access the meaning-making of 'pilgrims' to New Zealand's Tomb of the Unknown Warrior I carried out visitor research at the National War Memorial in Wellington. ${ }^{61}$ This took place in two phases. In the first phase I looked at two samples of 500 visitor comments left in the visitor books. Drawing on the information in the visitor comment books and the Tomb project objectives I then compiled a nine-question survey, which was completed by 20 visitors during one-to-one interviews at the Memorial.

\section{Thematic evaluation}

I organized the empirical data accumulated from visitor comments and interviewee responses into themes of place, remembrance, the tomb, gratitude, personal connection, condolence, peace, and nationalism. The most prevalent type of comment was related to the National War Memorial and its surrounds. These comments included general references to physical aspects of the memorial including its architecture, landscaping and maintenance (visitor comments in italics): This structure is an architectural gem [Male, England]. Other comments referred to specific details of the inscriber's visit or previous visits: 50 years of visiting this special place [Female, NZ]. As well as the physical elements of the memorial, visitors also commented on the emotional impact that the war memorial had on them. Some comments described it as powerful, moving and peaceful, while others emphasized the spirituality of the visitor experience and expressed sadness at the thousands of lives that were being memorialized: It makes my heart ache [Female, NZ].

Visitor comments emphasized the need to remember sacrifices New Zealanders have made in past wars: We will never forget the ones who gave their lives to protect others [Male, US]. For some visitors the Memorial was 
an important educational tool in increasing awareness, especially amongst younger generations, of the sacrifices of past generations: Wonderful monuments like this mean the youth of today won't forget [Unknown]. The majority of comments linked to the theme of remembrance employed traditional commemorative language such as 'We remember them' and 'Lest we forget' - phrases taken from the Ode of Remembrance read during memorial services on commemorative occasions such as Anzac Day. Although the majority of these comments positioned the inscriber as part of a collective of commemorators, others made a more personal statement: I came to commemorate those who fought and died for NZ [Male, NZ].

A number of visitor comments made direct reference to the Unknown Warrior. The majority of these comments were messages of welcome and emphasized the fact that he was home after a long time away. In a few cases, references were made to symbols of New Zealand national identity to reinforce this point: So happy to know you can hear the Tui sing again [Female, NZ]. Although the bulk of visitor comments concerning the Unknown Warrior were positive, a small number of comments raised issues concerning his anonymity and the terminology used in his title: Sad you couldn't identify him [Female, NZ]: 'Soldier' not Warrior! [Female, NZ].

Another set of comments expressed gratitude to those New Zealanders who served their country and lost their lives during times of war. Although the majority of comments focused on the Unknown Warrior and New Zealand war dead in general, several also acknowledged the service of veterans from specific wars: For all the men who went, sometimes against their will, to fight and be injured or die in the bloody jungles of Vietnam, we owe them honour no less than those who fought in any war [Male, NZ]. In addition to acknowledging war dead and veteran groups there were also similar comments addressed directly to the 'makers' or curators of the tomb and memorial: Thank you for this peaceful place [Female, NZ].

Some visitor comments highlighted personal connections with war dead. This type of entry commemorated the service of military ancestors and acknowledged their possible connection to the Unknown Warrior. The majority of the comments were intergenerational messages from children and grandchildren in memory of family members who had served in past wars: Sixty-three years ago today my father was shot down and killed in Germany. He was a pilot in 486 Squadron flying a Tempest [Female, NZ]. Within this category of visitor comment, a small number of comments made personal connections to the Unknown Warrior: Glad you're back in New Zealand Sid [Female, NZ].

Visitor comments employed traditional western funerary language to express their condolence and sympathy for the war dead commemorated at the National War Memorial. Expressions such as 'rest in peace' were 
prevalent in comments left in the immediate period following the interment of the Unknown Warrior. This may have been because the funerary aspects of this ceremony prompted visitors to use this terminology: Rest in peace. Sleep well and enjoy your new home [Female, NZ].

Another set of visitor comments was associated with the idea of peace. These comments focused on the human cost of war and expressed the hope that the sacrifices of New Zealand's war dead would not be in vain: Doesn't war suck! So many wasted lives [Male, NZ].

There were few overtly nationalistic comments: I feel proud to be a Kiwi. God bless all the soldiers willing to sacrifice their lives for $N Z$ [Female, NZ], while the final group of visitor comments were those that made nonspecific comments or no references at all. This selection included visitors who indicated why they did not say anything specific about their visit, as well as those who declined or were unable to elaborate on their experience for whatever reason: No words come to mind [Male, NZ].

A glance at some of the visitor comments made during the return of Canada's Unknown Soldier reveals similar themes to those in the National War Memorial visitor books. The Canadian comments were made in two ways. Members of the public were given the opportunity to visit the Unknown Soldier as he lay in state in Ottawa's Parliament Buildings, 25-28 May 2000. Before leaving the Hall of Honour some shared their reflections in a Visitors' Registry. For Canadians not able to pay their respects personally, a virtual Tomb Visitor's Book was established to allow people to leave their thoughts and reflections online. ${ }^{62}$

The majority of comments are expressions of gratitude for the Unknown Soldier's sacrifice: With loving gratitude and eternal thanks [Unknown, Canada]. Other comments note his contribution to the nation: Thank you for your sacrifice and those of your peers in helping others and making Canada a great country [Unknown, Canada] and the need to remember Canada's war veterans: The Tomb of the Unknown Soldier is a great honour for us to remember that many Canadians died for our freedom. I will always remind my daughter what Remembrance Day is all about [Male, Canada]. Several comments also highlight personal connections to the Unknown Soldier and soldier ancestors: This could have been my Grandfather, Pte Carly Tupper who fell at Ypres and has no known grave [Male, Canada]. Finally, a small minority of comments expressed the virtues of peace: war is stupid [Female, Canada] or focused on Tomb itself: I think the tomb was very interesting. What amazed me most was the size [Female, Canada].

Several linkages can be made between the themes above. The first is the relationship between themes of remembrance and place. Visitors commented on how the memorial's design and atmosphere assisted reflection: Quiet and serene surroundings to reflect on our fallen [Female, NZ]. On another 
level, visitors acknowledged the importance of the memorial for ensuring remembrance. Several suggested that the memorial should be a form of universal civic education: We must teach our children to appreciate your precious gift. I will visit your grave, and bring members of the next children, so they too, will remember [Female, Canada]. Related to this is the idea that the Tomb and Canada's Unknown Soldier should constitute a reminder of the cost of war and an exhortation to remember so that we never go to war again: Never forget the hardship so we can continue with the present [Male, NZ].

Themes of remembrance are also related to personal and family history. Visitors' personal connections encouraged them to commemorate friends and family members who had served and/or died during wartime. These comments highlighted the intergenerational connections and located the act of remembrance within a personal narrative: My grandmother's favourite cousin was killed December 23 1915. [She] always regretted never being able to visit his grave. Maybe this will make it easier for people ... to feel closer to a loved one whom they are unable to visit [Male, Canada]. Finally, expressions of gratitude and remembrance can be linked with aspects of nationalism. In communicating gratitude to their nation's war dead, visitors positioned their remembering within a collective national narrative: . . the Canadian government has done this for future generations of Canadians who would learn to understand why we have our freedom today because of the sacrifices made by Canadians who fought in the two world wars [Female, Canada]. In addition, the visitor comment books provided a platform for them to lobby other New Zealanders and Canadians to do the same: Every New Zealander should visit [Male, NZ].

\section{Visitor book comments}

The visitor comments above provide a picture of the personal reflections and interpretations of visitors at the National War Memorial over a threeyear period. The majority of these comments were, connected to ideas of place, family and ritual. In terms of place, visitors consistently linked the emotional aspect of their experience with the impact of the memorial environment on their remembrance. The Tomb and the surrounding Memorial were described as 'peaceful' and 'spiritual'; a place that enabled visitors to 'reflect', express their 'thanks' or 'heartache'. For these visitors the memorial is 'charged with meaning' - an expression used by Bruce Scates to describe the landscape encountered by visitors to the battlefield cemeteries at Gallipoli. ${ }^{63}$ Like Scates' pilgrims, visitors to the Memorial articulated their in relation to their own personal experiences. While I acknowledge that many of the comments are too succinct for detailed insight, there are glimpses. For example, an Australian veteran recalled serving alongside 
his 'Anzac brothers' in Vietnam; while a son remembered the grief of his mother who 'mourned everyday for her brother who survived Gallipoli and was killed in France, 1917'.

The importance of family connections is evident throughout the comments of visitors to the National War Memorial. Sons, daughters, nephews and nieces remember fathers and uncles who left for war but did not come back, while grandchildren and great-grandchildren acknowledge the service of soldier ancestors they have never met. In recent years, interest in family history has emerged as part of the 'rediscovery' of war memory and commemoration. ${ }^{64}$ War commemoration has flourished in countries like New Zealand, Australia, and Canada because war plays a central role in the mythology surrounding each country's national identity. The presence of soldier ancestors helps connect visitors to these national narratives and incorporates them into what Benedict Anderson has labelled 'imagined communities'. ${ }^{65}$

There were dissenters. While comments show that many visitors shared a sense of debt to those 'saviours' and 'protectors' that fought and died for 'our generation'; others commented on the waste and futility of war. The death of the Unknown Warrior and nearly 30,000 other New Zealanders was keenly felt by visitors who emphasized the importance of maintaining peace and using memorials as warnings against participating in future wars.

Many comments were left as messages of condolence. They express the hope that the Unknown Warrior 'Rest in Peace' - terminology adopted from Western funeral rituals: May you rest in heaven as you served your time down here [Female, NZ]. This type of comment is perhaps not surprising given the intense ritual and ceremony that accompanied the Unknown Warrior's return to New Zealand. His state funeral evoked widespread emotion amongst the New Zealand public.

The combination of highly publicized ceremonial ritual and interment of human remains seemed to resonate with New Zealand visitors to the memorial during this period. In a newspaper article published just after the establishment of the Tomb of the Unknown Warrior Jim Traue wrote that New Zealanders, especially those of European (Pakeha) descent, had embraced the return of the Unknown Warrior because it was public ritual with deep roots in European heritage. ${ }^{66}$ Since the time of the early Greek and Roman states, death and burial have been rites of passage indelibly linked to civic responsibility. The primary obligation of a citizen was to fight, and if necessary, die for the state. In return, civic honours were bestowed on those who made the ultimate sacrifice. This idea was widely adopted by nation-states looking to commemorate their fallen following the carnage of the First World War. New Zealand was no exception. During the 1920s and 1930s Anzac Day services were essentially re-enactments of a military 
funeral, complete with gun carriage, wreaths, firing party and playing of the Last Post. ${ }^{67}$ Over eighty years later, these same rituals were repeated during the return of the Unknown Warrior.

The level of emotion surrounding the Unknown Warrior's return is perhaps not surprising given the continued importance of war to public commemoration in New Zealand. In a country with few public rituals, Anzac Day remains the one day of the year where New Zealanders gather together and show emotion (sporting events aside). ${ }^{68}$ Unable to compete with the grand spectacles of national identity of the United States, Europe and Australia, Anzac Day provides an opportunity to publicly express what it means to be a New Zealander. ${ }^{69}$ Increasingly central to New Zealand's distinct sense of national identity has been the incorporation of Maori symbolism and ritual. Over the last twenty years, this cultural dynamism has extended into the area of war remembrance. ${ }^{70}$

The design of New Zealand's Tomb of the Unknown Warrior is a prime example. Rachel Buchanan points to the fact that the Tomb's exterior is a mix of references drawn almost exclusively from Maori culture. ${ }^{71}$ The bronze cover on the Tomb is described as a protective cloak over the Unknown Warrior. This description references Maori funeral (tangi) rituals in which a feather cloak is laid over the body of a dead person. ${ }^{72}$ Stars and/or crosses etched into cover of the Tomb are said to be the Southern Cross guiding the warrior's body home; a journey echoing the great migrations of Maori from Hawaikinui to New Zealand. Furthermore, the call (karanga) inscribed - in Maori and English - around the base of the tomb echoes the pain of distance felt by Maori and Pakeha who's loved ones died serving overseas..$^{73}$

While the surface of the tomb appears to highlight cultural difference, the body inside the Tomb occludes such distinctions and allows visitors to commemorate the sacrifice of an ordinary 'New Zealander'. Divested of all identifying features, including race, the Unknown Warrior '. . . could be anyone so represents everyone. ${ }^{74}$ This universal appeal is perhaps one of reasons for the groundswell of support given to the Unknown Warrior project as contemporary New Zealand, especially Pakeha New Zealand, becomes more receptive to ritual observances as a means of expressing community, establishing continuity with past, and providing a framework of collective meaning. ${ }^{75}$

\section{Survey responses}

The association of place, family, and ritual with contemporary war remembrance is also evident in the answers of survey respondents to questions about the significance of the Tomb of the Unknown Warrior. Respondents drew upon a combination of personal experience and collective national narrative to articulate their interpretations of the Tomb. Their 
responses emphasize the importance of New Zealand military ancestors in forming connections to the Unknown Warrior and how the design added value to visitors' sense of place and ritual.

Almost all respondents believed that it was important for New Zealand to have repatriated the remains of its own Unknown Warrior. The majority of responses were very nationalistic and questioned the relevance of having the British Unknown Warrior in Westminster Abbey represent New Zealand's war dead: Having our own TUW is very important. I'm a republican and I think we should have our own head of state and our own identity split from Britain. The return of the Unknown Warrior helps us reach that [Male, 67].

The return of the Unknown Warrior and the creation of the Tomb were seen as a mark of New Zealand's progress since the world wars and the days of the British empire: Sign of political maturity. New Zealand and the United Kingdom are going separate ways. New Zealand has fought in campaigns that the United Kingdom was not involved in i.e. Vietnam [Male, 51].

For some respondents the importance of returning an unknown warrior to New Zealand was couched in more practical terms and involved issues of accessibility and publicity: The TUW is terribly important. It's symbolically important to return our war dead separate to Britain. It's an accessibility issue. New Zealanders now have a place to come to in NZ to honour our unknown war dead. Not all of us have the means or opportunity to visit Westminster Abbey [Male, 25].

Only one respondent questioned the need to bring an Unknown Warrior back to New Zealand. This was on the basis that his remains had been lying undisturbed for nearly ninety years and the fact that it could not be proved unequivocally that he was a New Zealander: I'm not sentimental in that respect. I've had family members serve in the New Zealand Wars, at Gallipoli and in WW2. It brings home the futility of war. The fact is he was resting in peace and has now been brought back thousands of miles to his country of origin - if indeed this is his country of origin [Male, 72].

For most respondents the significance of the Tomb was as a focal point for war commemoration. Its location in Wellington helped centralize national war remembrance geographically and politically by providing an appropriate site from which to commemorate important national military anniversaries such as Anzac Day: The TUW is a focal point for commemoration and centralises remembrance. It is a national memorial [Female, 94].

Respondents suggested that the New Zealand government's involvement in the return of the Unknown Warrior and construction of the Tomb ensured the memorial had significant 'credibility and gravitas'. This status had been reinforced by the media coverage of the Unknown Warrior's arrival in New 
Zealand and the Armistice Day interment ceremony: The TUW provides a place for national recognition. I watched the [televised] service and was touched by the sand from different parts of New Zealand being interred with remains, and I'm not an army or military buff at all [Male, 58].

The fact that the Tomb contains human remains was an important fact for several respondents. For these visitors the Tomb was a grave where visitors could mourn the loss of family, however distant: The Tomb is a grave and is more about mourning rather than remembrance. You can walk past a cenotaph and it is about memory whereas the Tomb is much more personal because of the fact that it is a body inside. There is a greater sense of wairua [spirituality] because the Tomb has mauri [life force] [Female, 23].

For others the location of the Tomb was not as significant. For some respondents their local war memorial provided a more palpable link to relatives or family acquaintances because they could read the names of their soldier-ancestors: It doesn't have the same impact. Where we are from Wanganui the name of one of our relations is on a memorial stone near the war memorial. We have more of a connection to that than the TUW, which is more remote [Male, 72].

The majority of respondents did not express any sense of close personal connection to the Unknown Warrior. He was viewed as a purely symbolic representation of New Zealand's war dead buried overseas: The TUW is purely symbolic, although it does bring back memories of our ancestors who have fought in wars [Male, 58].

Any personal connections respondents made with the Unknown Warrior seemed to be dictated by the existence of New Zealand military ancestors; especially ancestors who had died during wartime and were buried overseas. In other words, the Unknown Warrior was seen as a far more tangible figure for those who had lost family, however distant, during war: I don't associate my relatives with the Unknown Warrior because they didn't die. Not the same form of remembrance as those who lost family [Male, 72].

For others the family connection with the Unknown Warrior was more palpable: I had a brother who served in the Royal New Zealand Air Force and was killed in Britain. My husband also served but came home. Our family has a military background. My father was a professional soldier who fought at Gallipoli [Female, 94].

For those remembering family members, place was an important consideration in forming a sense of connection with the Unknown Warrior: No personal connection here. That would be the Auckland War Memorial Museum. I was taken there when I was young and saw my GreatGrandfather's name on the wall. Seeing his name provided more of a connection [Female, 20]. 
The majority of respondents appreciated the simplicity of the Tomb's design. The design was modern yet understated, and did not glorify war unlike the grand and ornate memorials of the past. This helped the Tomb integrate harmoniously with the surrounding Memorial: Its integration with the steps and entrance. A simple, centred, and contemporary take on a classical shape. I like the use of the tukutuku panels as crosses [Male, 42].

There were references to materials and symbolism used on the Tomb but few were overtly nationalistic. Respondents seem especially drawn to the inscriptions: I like the written karanga; the pounamu crosses and the materials used. I also like the shape and the juxtaposition between the marble and bronze. Its position in the stairs means that the Tomb is part of the NWM [Female, 23].

Only a small number of respondents expressed criticism of the Tomb design. Some felt it was too simplistic and offered no visual impact. Some visitors felt the Tomb lacked pomp and pageantry, especially compared to overseas Unknown Soldier tombs. Some had more practical concerns about the exposed location and the lack of protection against human interference: The lid looks like a BBQ top - it's also discoloured. The Tomb is modern while the rest of the NWM is old. No eternal flame. It's underwhelming compared to the rest of the world [Female, 67]. Others were confused with elements of the Tomb's symbolism, especially the crosses, which seem too universal and not 'Kiwi' enough: The white crosses don't look very New Zealand to me [Male, 67].

\section{Conclusion}

The return of the Unknown Warrior was one the largest public ceremonial events ever held in New Zealand. New Zealanders, especially Pakeha/ European New Zealanders, were particularly receptive to the ceremonies because of their association with a European tradition. The return and burial of soldiers killed on the battlefield was a civic ritual that emerged in classic Greek and Roman states. Tied to the concept of citizenship, the return of the warrior, his procession through Wellington, and interment in the Tomb of the Unknown Warrior enabled Pakeha to establish a sense of community and continuity with the past.

Popular reaction to these ritual elements overlapped with official objectives of the project, namely the celebration of national identity and the establishment of a sense of continuity with the past in the interests of social cohesion. The popular reception given to the Unknown Warrior suggests that individual remembrance invokes broader national narratives.$^{76}$ It seems the 'cult of the fallen soldier' described by George Mosse continues to maintain its appeal in the twenty-first century, albeit in a different form. ${ }^{77}$ 
The passage of sombre pilgrimage and casual visitation to the National War Memorial yields insight into the intersection of family, national and personal memory evident everyday at the memorial - not just apparent in the very public ceremonies associated with the interment but visitation as a form of memorial ritual in its own right.

Modern war commemoration takes place in a 'post military society'.78 Despite the 'war on terror' and invasions of Iraq and Afghanistan, national security issues have largely diminished for countries like Australia, Canada, and New Zealand..$^{79}$ The nature of modern warfare means it is unlikely that countries will mourn loss of life on such a scale again. With little experience of the tragedy of major conflicts, citizens in contemporary societies instead face the challenge of trying not to forget them. The primary tools are war memorials, public rituals, literature, and war history projects.

The presence of memorials such as the Tomb of the Unknown Warrior adds to visitors' sense of national identity. The repatriation of unknown soldiers to Australia, Canada, and New Zealand illustrates the progress each country has made from British Dominion. Each tomb fits into a narrative of postcolonial independence, providing the opportunity for visitors to remember and honour the experiences of their soldiers, which were different from those of Great Britain. Visitors to the National War Memorial considered it only fitting that we had own Unknown Warrior rather employing the Westminster Abbey Tomb as a proxy national memorial.

While the remembrance space has widened, omissions remain. Just as Australia has struggled to fit early Aboriginal conflicts into official war memory, the New Zealand Wars remain absent from commemorations at the National War Memorial. The focus of remembrance remains exclusively on commemorating New Zealand's contribution to overseas wars, while our internal civil wars remain on the periphery of collective memory. These civil conflicts do not fit comfortably with the conventional cultural narrative of New Zealand and Australia. As such, they continue to be ignored at national memorials dedicated to remembering wars fought against an overseas enemy. Given this article primarily focuses on New Zealand/ European Pakeha visitors to the Tomb, there is opportunity for future studies to research Maori perspectives of the Unknown Warrior, especially with regard to war and treatment of the dead. Studies conducted within cultural or community groups could provide valuable insights into the ways in which stories about the past are handed down within families, or circulate amongst friends. Like Alistair Thomson's study of the Anzac legend in Australia, community-based research may reveal how different perspectives about war and commemoration circulate through towns, regions, nations and mass media. ${ }^{80}$ 
This article shows how public memorialization evolves alongside the prevailing political and cultural conditions. The Unknown Soldier projects in Australia, Canada and New Zealand have maintained the profile and impetus of war remembrance and commemoration. But they no longer promote sacrifice nor ease the grief of the bereaved. Visitors to the Tomb of the Unknown Warrior were influenced by a post-military narrative of war remembrance, in which the emphasis is on understanding the human experience of war rather than assuaging grief or promoting ideals of sacrifice or service. The anonymity of the remains enables visitors to make connections with soldier ancestors, while each Tomb provides a focal point for remembrance, ritual and commemoration. For these visitors, their 'boys' really have come home.

\section{APPENDIX}

My research methodology was based on qualitative research principles. I used visitor book analysis and open-ended surveys to move beyond observational and demographic research to explore the attitudes, values and feelings of visitors to the National War Memorial. ${ }^{81}$

Two samples of 500 visitor comments were collected from the National War Memorial visitor books during two periods: 11 November 2004 to 16 January 2005 and 11 November 2007 to 18 June 2008. Surveys were also conducted with 20 visitors to the National War Memorial over a three-month period: 29 April to 29 July 2009. The survey contained questions related to visitor demographics and visitation history, while four main questions asked for visitors' perceptions of the significance of the Tomb at both a national and personal level. Visitors were requested to complete a survey as they left. Representative sampling was attempted by using a systematic interval sampling method of one visitor per thirty-minute period.

Themes were identified within the visitor comments and survey responses using a constant comparative method of data analysis. Comments were grouped under an initial set of broad headings, which were reworked and revised until the full range of visitor responses had been categorized. Survey responses were analysed using the same method.

Several limitations in my visitor research must be noted. Visitor comments were often succinct, and only revealed a small aspect of the visitor's experience. The anonymity of comments and the absence of sociodemographic characteristics were also problematic in determining whether these visitors were representative. My survey sample was comprised solely of visitors of New Zealand European (Pakeha) descent. The small size of my research sample was determined by the conclusion that theoretical saturation had been achieved after 20 interviews. Respondents were providing similar 
responses to each question and I felt that additional surveys were unlikely to yield any new information.

1 Tim Shoebridge, National War Memorial \& Tomb of the Unknown Warrior, Wellington, 2009.

2 Kingsley Baird, 'The Tomb of the Unknown Warrior Te Toma o Te Toa Matangaro' http://www.kingsleybaird.com/index.php?sid=5, accessed 30 July 2008.

3 Timothy G. Ashplant, Graham Dawson and Michael Roper, eds, Commemorating War: The Politics of Memory, New Brunswick and London, 2004.

4 See Paul Fussell, The Great War and Modern Memory, London and New York, 1975; Alan Borg, War Memorials from Antiquity to the Present, London, 1991; and David Lloyd, Battlefield Tourism: Pilgrimage and Commemoration of the Great War in Britain, Australia, and Canada 1919-1939, Oxford, 1998.

5 See James E. Young, The Texture of Memory: Holocaust Memorials and Meaning in Europe, Israel, and America, New Haven, 1993; Kristin Ann Hass, Carried to the Wall: American Memory and the Vietnam Veterans Memorial, Berkeley and London, 1998; Daniel J. Sherman, The Construction of Memory in Interwar France, Chicago and London, 1999; and Joy Damousi, Living with the Aftermath: Trauma, Nostalgia and Grief in Post-War Australia, Cambridge, 2001.

6 See Jock Phillips, 'The quiet Western Front: the First World War and New Zealand memory', in Santanu Das, ed., Race, Empire and First World War Writing, Cambridge, 2011, p.245. Phillips identifies a number of studies crucial to the 'rediscovery' New Zealand's interest in its war history: Chris Pugsley's history of the Gallipoli campaign (Gallipoli: The New Zealand Story, Auckland, 1984); the interviews with First World War veterans in Maurice Shadbolt's, Voices of Gallipoli, Auckland, 1988; and Nicholas Boyack and Jane Tolerton's, In the Shadow of War: New Zealand Soldiers Talk About World War One and Their Lives, Auckland, 1990.

7 Since 2001 the Ministry for Culture and Heritage has produced a series of books based on interviews with New Zealand Second World War veterans. For details of these publications see 'From Memory -war oral history programme' http://www.nzhistory.net.nz/hands /from-memory/from-memory. See also Deborah Challinor, Grey Ghosts: New Zealand Vietnam Vets Talk About Their War, Auckland, 1998; Scott Worthy, 'Communities of Remembrance: Making Auckland's War Memorial Museum' in Journal of Contemporary History, 39, 4 (2004), pp.599-618; and Sandy Callister, The Face of War: New Zealand's Great War Photography, Auckland, 2008.

8 On war memorializing in Britain and Europe, see George L. Mosse, Fallen Soldiers: Reshaping the Memory of the World Wars, Oxford, 1990; Jay Winter, Sites of Memory, Sites of Mourning: The Great War in European Cultural History, Cambridge, 1995; and Alex King, Memorials of the Great War in Britain: The Symbolism and Politics of Remembrance, Oxford, 1998. On a history of war memorials in New Zealand and Australia see Chris Maclean and Jock Phillips, The Sorrow and the Pride: New Zealand War Memorials, Wellington, 1990; and K.S. Inglis, Sacred Places: War Memorials in the Australian Landscape, Melbourne, 1998.

9 Benedict Anderson, Imagined Communities: Reflections on the Origin and Spread of Nationalism, London, 1991.

10 Mosse, Fallen Soldiers. 


\section{The Tomb of the Unknown Warrior}

11 Winter, Sites of Memory.

12 On 11 November 1920 huge crowds in London and Paris watched as the remains of a First World War soldier were carried through the streets of each city to be reburied at a sacred site in the heart of both capitals.

13 Mosse, Fallen Soldiers. The practice of entombing unknown soldiers has its origins in ancient Greece. In Thucydides' account of the Athenian ceremony to honour their dead in the war against Sparta he describes the inclusion of an empty coffin containing the bones of 'the missing'. The death, burial and commemoration of war dead were rites of passage linked to civic responsibility - every Athenian was obligated to fight and if necessary die for the city in return for the privileges of citizenship. See K.S. Inglis, 'Entombing Unknown Soldiers', Journal of the Australian War Memorial (JAWM), 23 (1993), pp.4-12; Polly Low, 'Commemoration of War Dead in Classical Athens: Remembering Defeat and Victory', in David M. Pritchard, ed., War, Democracy and Culture in Classical Athens, Cambridge, 2010, pp.341-56.

14 Inglis, 'Entombing Unknown Soldiers'.

15 New Zealand Parliamentary Debates, 1921, 192, p.213. The Ashburton Guardian (12 November 1921), and Evening Post (14 November 1921) published short articles about William Jennings suggestion that the country repatriate an 'unknown New Zealand warrior' but it is unclear whether this enquiry generated any real public interest. By this time, many communities in New Zealand had built their own war memorials and the government had allocated $£ 100,000$ for a national war memorial, the first stage of which was built in 1932 .

16 Dominion Post, 11 November 2004.

17 Shoebridge, National War Memorial.

18 A carillon is a musical instrument consisting of at least 23 bells tuned chromatically to create a harmonious effect. At present, the Carillon at the Memorial has 74 bells, which makes it the third largest in the world.

19 Anzac Day is the main military anniversary in New Zealand, Australia and Turkey. It commemorates the landing of New Zealand and Australian troops at Gallipoli in Turkey, 25 April 1915.

20 Shoebridge, National War Memorial.

21 Kippenberger to Minister of Internal Affairs, 15 December 1950, Department of Internal Affairs.

22 McGibbon to Acting General Manager, Heritage Group, 11 November 1999, Department of Internal Affairs.

23 Ian McGibbon, New Zealand Battlefields and Memorials of the Western Front, Auckland, 2001.

24 The co-ordinating committee included representatives from the New Zealand Defence Force, Veterans' Affairs New Zealand, Department of Internal Affairs (Visits and Ceremonial Office), Te Puni Kokiri/Ministry of Maori Development, Department of Prime Minister and Cabinet, and the Ministry of Foreign Affairs and Trade; and non-government organizations such as the National War Memorial Advisory Council, the New Zealand Historic Places Trust, Royal New Zealand Returned Services' Association, Te Ati Awa (represented by the Wellington Tenths Trust), and the Wellington City Council.

25 'Tomb of the Unknown Warrior Project: Key messages/themes', Ministry for Culture and Heritage, 2003. 


\section{Journal of New Zealand Studies}

26 Professor Robert Jahnke is now Head of Maori Studies at Massey University in Palmerston North, New Zealand. Examples of his artwork stand at Te Papa (Wellington), Sky City Casino (Auckland), Wellington High Court, and Taharora Marae in Waipiro Bay.

27 After writing to the Prime Minister and the Ministry for Culture and Heritage, PHANZA published an article in their April 2003 Phanzine newsletter, highlighting the organization's concerns about the proposed changes to the memorial and questioning why heritage organizations such as the Ministry and New Zealand Historic Places Trust had approved such an invasive design. See T. Nightingale, 'Not So Sacred Ground - the National War Memorial', Phanzine, 9, 1 (2003), pp.4-5.

28 Sunday Star Times (SST), 6 April 2003.

29 On the posters was written; 'Lest we forget our Heritage - Historic Places Trust Category 1 steps/70yr old pohutukawa trees will be unnecessarily demolished next month by order of Minister for Arts Culture and Heritage, Prime Minister Helen Clark. Please write to Helen Clark now'. All posters were removed before the Anzac service began.

30 According to the Wellington City Council heritage listing for the National War Memorial, the steps and forecourt were not part of the memorial, despite the fact that they had been built at the same time as the Carillon in 1931-1932 (S. Butterworth, "National War Memorial', Phanzine, 9, 2 (2002), p.4). The Ministry, supported by the NZHPT and other project stakeholders, was happy with this interpretation and by May 2003 construction of the Tomb was ready to begin.

31 Matthews to Minister for Arts, Culture and Heritage, 18 November 2003, Ministry for Culture and Heritage, BR2004/475.

32 Ministry for Culture and Heritage, 2005 Annual Report, Wellington, 2005.

33 Helen Clark, Address at Memorial Service for Unknown Warrior, 11 November 2004. For full transcript of this speech see http://www.beehive.govt.nz/speech/address-memorial -service-unknown-warrior.

34 Winter, Sites of Memory.

35 Ashplant et al, Commemorating War.

36 Critics argue that a more integrated account of the processes that link the individual, civil society and the state can be found in a third body of work on war memory that uses oral-history and life-story methods.

37 M. Shaw, 'Past Wars and Present Conflicts: From the Second World War to the Gulf', in Martin Evans and Kenneth Lunn, eds, War and Memory in the Twentieth Century, Oxford, 1997.

38 Jay Winter and Antoine Prost, The Great War in History, Cambridge, 2005.

39 Ibid.

40 D. Marshall, 'Making sense of remembrance', Social \& Cultural Geography, 5, 1 (2004), pp.37-54.

41 S. Nathan, 'War Memorials' http://blog.teara.govt.nz/2008/04/23/war-memorials/, accessed 19 June 2008.

42 Ibid.

43 Young, The Texture of Memory.

44 Artist Jochen Gerz built both memorials. The Harburg Monument was a 12-metre tall square column engraved with the signatures of the city's residents and visitors. The column was lowered eight times between 1986 and 1993 until it disappeared from view. 


\section{The Tomb of the Unknown Warrior}

The Saarbrücken Monument saw paving stones in front of the Saarbrücken Castle removed and replaced with ones bearing the names of Jewish cemeteries used in Germany prior to the Second World War. These stones were placed with the inscription facing the ground.

45 New Zealand Herald, 23 February 2005.

46 Inglis, Sacred Places.

47 Stephen Clarke, 'ANZAC Day in Aotearoa: Yesterday, Today, Tomorrow', War and Remembrance Conference, Stout Research Centre, Victoria University of Wellington, 2 May 2008.

48 Liz Reed, Bigger Than Gallipoli: War, History and Memory in Australia, Crawley, 2004.

49 Indigenous Australians at War, 'Memorials' http://www.fortunecity.com/meltingpot /statuepark/620/memorial.html, accessed 29 March 2011.

50 Inglis, Sacred Places, pp.457-8.

51 The Royal Canadian Legion, Tomb of the Unknown Soldier Project History, Ottawa, 2001, p.105.

52 A. Hoefnagels, 'Remembering Canada's Forgotten Soldiers at Contemporary Powwows', Canadian Journal for Traditional Music, 28 (2001).

53 Veterans Affairs Canada, 'National Aboriginal Veterans Monument' http://www.veterans .gc.ca/eng/sub.cfm?source=feature/abmem, accessed 13 February 2011.

54 Kathryn Hunter, 'States of Mind: Remembering the Australian-New Zealand Relationship', JAWM, 36 (2002).

55 Rachel Buchanan, 'The Dementia Wing of History' Cultural Studies Review (CSR), 13, 1 (2007), pp.173-86.

56 The New Zealand Wars (1843-1875) were a series of armed conflicts fought between Maori and British imperial forces, settler militia, and their Maori allies. The wars were fought over a number of issues, most notably Maori land being sold to the (white) settler population.

57 Buchanan, 'The Dementia Wing of History', pp.179-180.

58 Ibid.

59 See Thomson, Anzac Memories; and Bruce Scates, Return to Gallipoli: Walking the Battlefields of the Great War, Cambridge, 2006.

60 Scates, Return to Gallipoli.

61 See Appendix for a description of research methodology, data collection and analysis.

62 Selections of these comments appear on the Veterans Affairs Canada website. There are 38 comments from the Hall of Honour Visitors' Registry (25-28 May 2000) and 218 comments from the Virtual Tomb Visitor's book (17 May 2000 - 10 September 2002). See Veterans Affairs Canada, 'Hall of Honour Visitors' Registry' http://www .veterans.gc.ca/eng/sub.cfm?source=Memorials/tomb/visitorbook/registry and 'Virtual Tomb Visitor's Book' http://www.veterans.gc.ca/eng/sub.cfm?source=Memorials/tomb /visitorbook, both accessed 13 February 2011.

63 Scates, Return to Gallipoli.

64 Clarke, 'ANZAC Day in Aotearoa'.

65 Anderson, Imagined Communities. 


\section{Journal of New Zealand Studies}

66 The Press (TP), 10 January 2005.

67 Clarke, 'ANZAC Day in Aotearoa'.

68 Ibid.

69 TP, 10 January 2005.

70 Clarke, 'ANZAC Day in Aotearoa'.

71 Buchanan, 'The Dementia Wing of History', p.181.

72 National War Memorial, 'Tomb of the Unknown Warrior - The Tomb Design' http: //www.nationalwarmemorial.govt.nz/tomb.html, accessed 29 March 2011.

73 Buchanan, CSR, p.181.

74 Buchanan, CSR.

75 TP, 10 January 2005.

76 See Misztal, Theories of Social Remembering and Thomson, Anzac Memories.

77 Mosse, Fallen Soldiers.

78 Shaw, 'Past Wars and Present Conflicts'.

79 As of March 2011 Australia (1550), Canada (2900), and New Zealand (236) had troops stationed in Afghanistan as part of the International Security Assistance Force (ISAF). Twenty-three Australian, 153 Canadian, and two New Zealand soldiers have been killed in combat or as a result of accidents in Afghanistan since 2002.

80 Thomson, Anzac Memories.

81 For a detailed description of research methodology, data collection and analysis see Gareth Phipps, 'Bringing our boy home: The Tomb of the Unknown Warrior, its visitors, and contemporary war remembrance in New Zealand', MA thesis, Victoria University, Wellington, 2010, pp.28-64. 